This item was submitted to Loughborough's Research Repository by the author.

Items in Figshare are protected by copyright, with all rights reserved, unless otherwise indicated.

\title{
Formative assessment lessons
}

PLEASE CITE THE PUBLISHED VERSION

https://doi.org/10.1007/978-3-319-73748-5_2

\section{PUBLISHER}

(C) Springer

\section{VERSION}

AM (Accepted Manuscript)

\section{PUBLISHER STATEMENT}

This work is made available according to the conditions of the Creative Commons Attribution-NonCommercialNoDerivatives 4.0 International (CC BY-NC-ND 4.0) licence. Full details of this licence are available at: https://creativecommons.org/licenses/by-nc-nd/4.0/

\section{LICENCE}

CC BY-NC-ND 4.0

\section{REPOSITORY RECORD}

Swan, Malcolm, and Colin Foster. 2019. "Formative Assessment Lessons". figshare. https://hdl.handle.net/2134/37556. 


\title{
CHAPTER X
}

\section{FORMATIVE ASSESSMENT LESSONS}

\author{
Malcolm Swan, School of Education, University of Nottingham, UK \\ Colin Foster, School of Education, University of Nottingham, UK
}

Formative assessment is the process by which teachers and students gather evidence of learning and then use this to adapt the way that they teach and learn in the classroom. In this paper, we describe a design-research project in which we integrated formative assessment into mathematics classroom materials. We outline two examples of formative assessment lessons, one concept-based and the other problem-solving, highlighting the important roles within them of pre-assessment, formative feedback questions and sample work for students to critique.

Keywords: conceptual understanding, formative assessment, problem solving, mathematics task design, teacher professional development

\subsection{INTRODUCTION}

High-quality formative classroom assessment has the potential to produce substantial student learning gains (Black et al. 2003; Black and Wiliam 1998, 1999). We follow Black and Wiliam's definition that:

Practice in a classroom is formative to the extent that evidence about student achievement is elicited, interpreted, and used by teachers, learners, or their peers, to make decisions about the next steps in instruction that are likely to be better, or better founded, than the decisions they would have taken in the absence of the evidence that was elicited. (2009, p. 9, original emphasis) 
Designing mathematics lessons that embed high-quality formative assessment practices could lead to better learning in those lessons, and could also play a part in supporting teachers in developing their formative assessment practices more widely in other mathematics lessons.

In 2010, with funding from the Bill and Melinda Gates Foundation, we began the Mathematics Assessment Project (MAP) to support US Middle and High Schools in implementing the new Common Core State Standards for Mathematics (CCSSM). ${ }^{1}$ These standards place a renewed focus on conceptual understanding and on the development of practices $^{2}$ (or processes) that should permeate all mathematical activity. In this project, we explored the research question: How can well-designed materials enable teachers to make highquality formative assessment an integral part of the implemented curriculum in their classrooms, even where linked professional development support is limited or non-existent?

This ambitious goal was motivated by four empirical findings. First, that professional development support is, in practice, in most places, sharply limited in quantity and in the quality of its leaders, and currently few have much deep experience of formative assessment. Second, the development of formative assessment expertise through professional development needs a program that lasts at least two years for significant impact (e.g., Wiliam et al. 2004). Third, most mathematics teachers rely on teaching materials, even when on familiar ground; thus, it is unreasonable to expect them to face the greater challenges of "adaptive expertise" (Hatano, and Inagaki 1986) within formative assessment without well-engineered support. Finally, it is our experience that teachers, like students, learn strategies best through constructive generalization

\footnotetext{
1 See http://www.corestandards.org/Math/.

2 The eight CCSSM Standards for Mathematical Practice are: (i) Make sense of problems and persevere in solving them; (ii) Reason abstractly and quantitatively; (iii) Construct viable arguments and critique the reasoning of others; (iv) Model with mathematics; (v) Use appropriate tools strategically; (vi) Attend to precision; (vii) Look for and make use of structure; and (viii) Look for and express regularity in repeated reasoning.
} 
of principles from specific high-quality experiences. We see these lessons as supporting such experiences - as well as providing a 'protein supplement' to a generally carbohydrate curriculum diet. It was our goal that over time teachers transfer some aspects of these strategies into their existing practice, with or without the professional development support for which the project also developed materials. There is now some evidence of this happening (see Section 6).

The MAP project developed over 100 formative assessment lessons, called Classroom Challenges. Each lesson consists of student resources and an extensive teacher guide. ${ }^{3}$ In this chapter, we describe the research-based design of these materials and outline two examples, one concept-based and the other focused on supporting students' problem-solving strategies. We highlight across both kinds of lessons the important roles of pre-assessment, formative feedback questions, and pre-designed sample work for students to critique. We also articulate how the interaction between the three agents of formative assessment (teachers, learners, and their peers) and the three main aspects of formative assessment (identifying where learners are in their learning, where they are going, and how to bridge the gap) is manifest in the lesson structures. (See also Cusi et al. and Wright et al. this volume). This interaction, or the "five key strategies" of formative assessment (Table X.1), was first articulated by Wiliam and Thompson (2007). Finally, we offer evidence from early independent studies that suggest that these lessons can indeed enable teachers to redefine the classroom contract.

Table X.1 Key strategies of formative assessment

$$
\text { Where the learner is going } \begin{aligned}
& \text { Where the learner is right } \\
& \text { now }
\end{aligned} \text { How to get there }
$$

${ }^{3}$ These lessons are available free on the website: $\mathrm{http}: / /$ map.mathshell.org. 


\begin{tabular}{llll}
\hline Teacher & $\begin{array}{l}\text { 1. Clarifying learning } \\
\text { intentions and criteria for } \\
\text { success }\end{array}$ & $\begin{array}{l}\text { 2. Engineering effective class- } \\
\text { room discussions and other } \\
\text { learning tasks that elicit } \\
\text { evidence of student } \\
\text { understanding }\end{array}$ & $\begin{array}{l}\text { 3. Providing } \\
\text { feedback that } \\
\text { moves learners } \\
\text { forward }\end{array}$ \\
\hline \multirow{2eer}{*}{$\quad \begin{array}{l}\text { Understanding and sharing } \\
\text { learning intentions and } \\
\text { criteria for success }\end{array}$} & $\begin{array}{l}\text { 4. Activating students as instructional resources for } \\
\text { one another }\end{array}$ \\
\hline \multirow{2earner}{*}{$\begin{array}{l}\text { Understanding and sharing } \\
\text { learning intentions and } \\
\text { criteria for success }\end{array}$} & $\begin{array}{l}\text { 5. Activating students as the owners of their own } \\
\text { learning }\end{array}$ \\
\hline
\end{tabular}

\subsection{THEORETICAL FRAMEWORK FOR TASK DESIGN}

The CCSSM make it clear that the goals of the new curriculum are to foster a deeper, connected conceptual understanding of mathematics, along with the strategic skills necessary to tackle nonroutine problems. In our work, we found it necessary to distinguish between lessons that are designed to foster conceptual development and those that are intended to develop problemsolving strategies. In the former, the focus of student activity is on the analysis and discussion of different interpretations of mathematical ideas, while in the latter the focus is on discussing and comparing alternative approaches to problems. The intention was that concept lessons might be used partway through the teaching of a particular topic, providing the teacher with opportunities to assess students' understanding and time to respond adaptively. Problem-solving lessons were designed to be used more flexibly - for example, between topics - to assess how well students could select already familiar mathematical techniques to tackle unfamiliar, non-routine problems, and thus provide a means for improving their strategic awareness. Importantly, for this to be effective, the technical demands of the task must be low, to allow processing capacity for students to focus on the strategic aspects of the problem. To this end, we recommend that these lessons should depend on content taught up to two years previously. 
The tasks that we selected for the concept-based Classroom Challenges were designed to foster collaborative sense-making. Sierpinska (1994) suggests that people feel that they have understood something when they have achieved a sense of order and harmony, where there is a 'unifying thought' of simplification, of seeing an underlying structure and a feeling that the essence of an idea has been captured. She lists four mental operations involved in understanding: identification: we can bring the concept to the foreground of attention, name and describe it; discrimination: we can see similarities and differences between this concept and others; generalisation: we can see general properties of the concept in particular cases of it; synthesis: we can perceive a unifying principle. (p. 32)

To these, we add the notion of representation: when we understand something, we are able to characterise it in a variety of ways: verbally, visually and/or symbolically.

In the light of this framework, we developed four genres of tasks for our conceptdevelopment lessons (Table X.2). The first two rows refer to activities with mathematical objects (classifying and representing them), the third refers to making conjectures and statements about those objects, and the fourth refers to the identification of situations within which those objects may be found. 
Table X.2 Task genres for concept development

\begin{tabular}{ll}
\hline Task genres & Sample classroom activities \\
\hline $\begin{array}{l}\text { Classify and define } \\
\text { mathematical objects and } \\
\text { structures }\end{array}$ & $\begin{array}{l}\text { Identifying and describing attributes and sorting objects } \\
\text { accordingly. }\end{array}$ \\
\hline Creating and identifying examples and non-examples. \\
Creating and testing definitions. \\
$\begin{array}{l}\text { Represent and translate } \\
\text { between mathematical concepts } \\
\text { and their representations }\end{array}$ & $\begin{array}{l}\text { Interpreting a range of representations including diagrams, } \\
\text { Translating between representations and studying the co- } \\
\text { variation between representations. }\end{array}$ \\
\hline $\begin{array}{l}\text { Justify and/or prove } \\
\text { mathematical conjectures, } \\
\text { procedures and connections }\end{array}$ & $\begin{array}{l}\text { Making and testing mathematical conjectures and } \\
\text { procedures. }\end{array}$ \\
& $\begin{array}{l}\text { Identifying examples that support or refute a conjecture. } \\
\text { Creating arguments that explain why conjectures and } \\
\text { procedures may or may not be valid. }\end{array}$ \\
\hline $\begin{array}{l}\text { Identify and analyze structure } \\
\text { within situations }\end{array}$ & $\begin{array}{l}\text { Studying and modifying mathematical situations. } \\
\text { Exploring relationships between variables. }\end{array}$ \\
\hline
\end{tabular}

The problem-solving Classroom Challenges were designed to assess and improve the capability of students to solve multi-step, non-routine problems and to extend this to the formulation and tackling of problems from the real world. We define a problem as a task that the individual wants to tackle, but for which he or she does not have access to a straightforward means of solution (Schoenfeld 1985). One consequence of this definition is that it is pedagogically inconsistent to design problem-solving tasks for the purpose of practising a specified procedure or developing an understanding of a particular concept. In order to develop strategic competence - the "ability to formulate, represent, and solve mathematical problems" (Kilpatrick et al. 2001, p. 116) - students must be free to experiment with a range of approaches. 
They may or may not decide to use any particular procedure or concept; these cannot be predetermined. Some task genres and sample classroom activities for problem solving are shown in Table X.3.

We see problem solving as being contained within the broader processes of mathematical modelling. Modelling additionally requires the formulation of problems by, for example, restricting the number of variables and making simplifying assumptions. Later in the process, solutions must be interpreted and validated in terms of the original context.

Table X.3 Task genres for problem-solving lessons

\begin{tabular}{ll}
\hline Task genres & Sample classroom activities \\
\hline $\begin{array}{l}\text { Solve a non-routine problem by } \\
\text { creating an extended chain of }\end{array}$ & Selecting appropriate mathematical concepts and \\
reasoning & procedures. \\
& Planning an approach. \\
& Carrying out the plan, monitoring progress and changing \\
direction, where necessary. & Reflecting on solutions; examining for reasonableness \\
& within the context. \\
& Reflecting on strategy; where might it have been \\
& improved? \\
\hline $\begin{array}{l}\text { Formulate and interpret a } \\
\text { mathematical model of a }\end{array}$ & Making suitable assumptions to simplify a situation. \\
situation that may be adapted & Representing a situation mathematically. \\
and used in a range of situations & Identifying significant variables in situations. \\
& Generating relationships between variables. \\
& Identifying accessible questions that may be tackled within \\
& a situation. \\
& Interpreting and validating a model in terms of the context. \\
\hline
\end{tabular}




\subsection{DESIGN-BASED METHODOLOGY}

Our method for lesson design was based on design-research principles, involving theory-driven iterative cycles of design, enactment, analysis and redesign (Barab and Squire 2004; Bereiter 2002; Cobb et al. 2003; DBRC 2003; Kelly 2003; van den Akker et al. 2006). In contrast to much design research, we worked to ensure that the products were robust in large-scale use by fairly typical end-users; thus, engaging in what Burkhardt (2006) has termed "engineering research."

Each lesson was developed, through two iterative design cycles, and trialled in three or four US classrooms between each revision. This sample size enabled us to obtain rich, detailed feedback, while also allowing us to distinguish general implementation issues from more idiosyncratic variations by individual teachers. Revisions were based on structured, detailed feedback from experienced local observers in California, Rhode Island, and the Midwest. Overall, we obtained approximately 700 observer reports of lessons from over 100 teachers (in over 50 schools) using these materials. We also observed many of the lessons first-hand in UK schools. On this basis, the lessons were revised. These lessons have subsequently been researched by other independent organizations (see Section 6). It is worth noting that this engineering approach is more expensive than the 'authorship' model that is traditional in education. Nonetheless, even if widely adopted, the cost would be negligible within the overall running costs of an education system. We believe that it is the only approach - standard in other fields - that can reliably combine ambition of goals with robustness in practical use.

We now describe two examples of the formative assessment lessons that we developed, one concept-based and the other problem-solving (Swan and Burkhardt 2014). Each lesson was designed to occupy about 45 minutes of classroom time and to be worked on collaboratively. 
Complete lesson guides for these lessons may be downloaded for free from http://map.mathshell.org.

\subsection{A CONCEPT-DEVELOPMENT LESSON}

The objective of this lesson, Distance-Time Graphs, is to provide a means for a teacher to formatively assess students' capacity to interpret graphs. The lesson is preceded by a short diagnostic assessment, designed to expose students' prior understandings and interpretations (Figure X.1). We encourage teachers to prepare for the lesson by reading through students' responses and by preparing probing questions that will advance student thinking. They are advised not to score or grade the work. Through our trials of the task, we developed a 'common issues table' (Figure X.1) that forewarns teachers of some common interpretations that students may have, and suggests questions that the teacher might pose to advance thinking. This form of feedback has been shown to be more powerful than grades or scores, which detract from the mathematics and encourage competition rather than collaboration (Black et al. 2003; Black and Wiliam 1998). Some teachers write their questions on the student work whereas others prepare short lists of questions for the whole class to consider.

The lesson itself is then structured in five parts:

1. Make existing concepts and methods explicit. The lesson begins with an initial task to clarify the learning intentions, create curiosity, help students become aware of their own intuitive interpretations and model the level of reasoning expected in the main activity (Strategy 1). ${ }^{4}$ The teacher invites and probes explanations, but does not correct students or attempt to reach resolution at this point.

\footnotetext{
4 The strategy numbers refer to the formative assessment strategies listed in Table X.1.
} 
2. Collaborative activity: Matching graphs, stories and tables. This phase is designed to create student-student discussions in which they share and challenge each other's interpretations (Strategy 2). Ten distance-time graphs are to be matched with nine 'stories' (the 10th to be constructed by the student). When the cards have been discussed and matched, the teacher distributes a further set of cards that contain distance-time tables of numerical data. These provide feedback, by enabling students to check their own responses and reconsider the decisions that have been made. Students collaborate to construct posters displaying their reasoning. While students work, the teacher is encouraged to ask the prepared questions from the initial diagnostic assessment (Strategy 3).

3. Inter-group discussion: Comparing interpretations. Students' posters are displayed and students visit each other's posters and check them, demanding explanations (Strategy 4).

4. Plenary discussion. Students revisit the task that was introduced at the beginning of the lesson, and resolution is now sought. Drawing on examples of student work produced during the lesson, the teacher directs attention to the significant concepts that have arisen (Strategy 2).

5. Individual work: Improving solutions to the pre-assessment task. Students now revisit the work they did on the pre-assessment task. They describe how they would now answer the task differently and write about what they have learned (Strategy 5). 


\section{Journey to the bus stop}

Every morning, Tom walks along a straight road from his home to a bus stop, a distance of 160 meters. The graph shows his journey on one particular day.

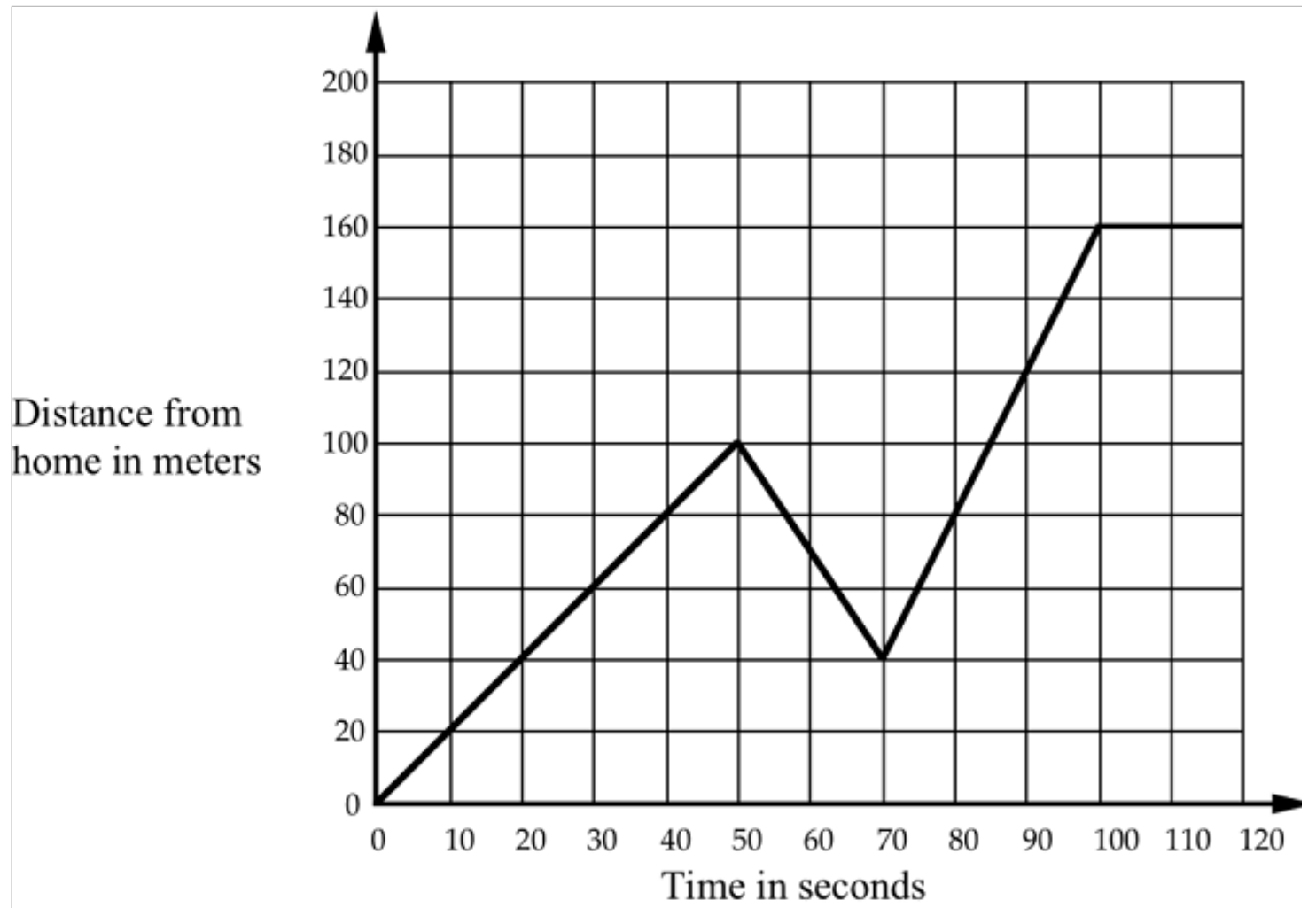

1. Describe what may have happened.

Include details like how fast he walked.

2. Are all sections of the graph realistic?

Fully explain your answer.

Issue

Student interprets the graph as a picture

For example: The student assumes that as the graph goes up and down, Tom's path is going up and down or assumes that a straight line on a graph means that the motion is along a straight path.

\section{Suggested questions and prompts}

- If a person walked in a circle around their home, what would the graph look like?

- If a person walked at a steady speed up and down a hill, directly away from home, what would the graph look like?

- In each section of his journey, is Tom's speed steady or is it changing? How do you know?

- How can you figure out Tom's speed in each section of the journey? 


\section{Student interprets the graph as speed-time}

The student interprets a positive slope as 'speeding up' and a negative slope as 'slowing down'.
- If a person walked for a mile at a steady speed, away from home, then turned round and walked back home at the same steady speed, what would the graph look like?

- How does the distance change during the second section of Tom's journey? What does this mean?

- How can you tell if Tom is traveling away from or towards home?

Figure X.1 Initial assessment task: Journey to the bus stop, and an extract from the associated 'Common issues table'

\subsection{A PROBLEM-SOLVING LESSON}

Our trials showed that teachers find it difficult to interpret and monitor students' extended reasoning during a problem-solving lesson, and very hard to select which students to invite to talk about it during whole-class discussion. We therefore decided to precede each lesson with a preliminary assessment in which students tackled a substantial problem individually. The teacher reviews a sample of the students' initial attempts and identifies the main issues that need addressing. The focus is on approaches to the problem. If time permits, teachers write feedback questions on each student's work, or alternatively prepare questions for the whole class to consider.

For example, one High School problem poses the following question:

A poster asserts that one female cat can have 2000 descendants in 18 months.

Is this realistic?

This problem is accompanied by five pieces of information:

- The length of a cat's pregnancy is about 2 months;

- Cats can first get pregnant when they are 4 months old;

- Cats normally have 4 to 6 kittens in a litter; 
- A female cat can have about 3 litters per year;

- Cats stop having kittens when they are 10 years old. ${ }^{5}$

The lesson is structured as follows:

1. Introduction: Responding to formative feedback. The teacher re-introduces the main task for the lesson and returns students' initial attempts, along with some formative questions. Students have a few minutes to read these questions and respond to them individually (Strategy 3). 'Common issues' have been identified from trials and these are provided for teachers to use (Figure X.2).

\begin{tabular}{ll}
\hline Issue & Suggested questions and prompts \\
\hline Has difficulty starting & $\begin{array}{l}\text { Can you describe what happens during the first five } \\
\text { months? }\end{array}$ \\
\hline $\begin{array}{l}\text { Does not develop a suitable } \\
\text { representation }\end{array}$ & $\begin{array}{l}\text { Can you make a diagram or table to show what is } \\
\text { happening? }\end{array}$ \\
\hline Work is unsystematic & $\begin{array}{l}\text { Could you start by just looking at the litters from the first } \\
\text { cat? }\end{array}$ \\
& What would you do after that? \\
\hline Develops a partial model & $\begin{array}{l}\text { Do you think the first litter of kittens will have time to } \\
\text { grow and have litters of their own? What about their } \\
\text { kittens? }\end{array}$ \\
\hline Does not make reasonable & What assumptions have you made? Are all your kittens \\
assumptions & born at the beginning of the year? Are all your kittens \\
& females? \\
\hline
\end{tabular}

Figure X.2 An extract from the 'Common issues table' for Having Kittens

2. Group work: Comparing strategic approaches. In small groups, students are asked to discuss each person's work and then produce a poster showing a joint solution that is better

\footnotetext{
5 This task was originally designed by Lesley Ravenscroft and appears courtesy of the Bowland Charitable Trust.
} 
than the individual attempts. Groups are organized so that students with contrasting ideas are paired, thus promoting peer assessment (Strategy 4). The teacher's role is to observe groups and challenge students using the prepared questions to refine and improve their strategies (Strategy 2). The teacher may at this point ask students to review the strategic approaches produced by other groups in the class, and justify their own. Additionally, the teacher may introduce up to four pieces of "pre-designed sample student work" (Evans and Swan 2014), provided in the materials, which are chosen to highlight alternative approaches. Each piece of work is annotated with questions that focus students' attention (Figure X.3).

3. Group work: Refining solutions. Students revisit the task and try to use insights to further refine their solution (Strategy 4).

4. Whole-class discussion: Reviewing learning. The teacher holds a plenary discussion to focus on the processes involved in the problem, such as the implications of making different assumptions, the power of alternative representations and the general mathematical structure of the problem.

\section{Questions for students:}

Wayne's solution 


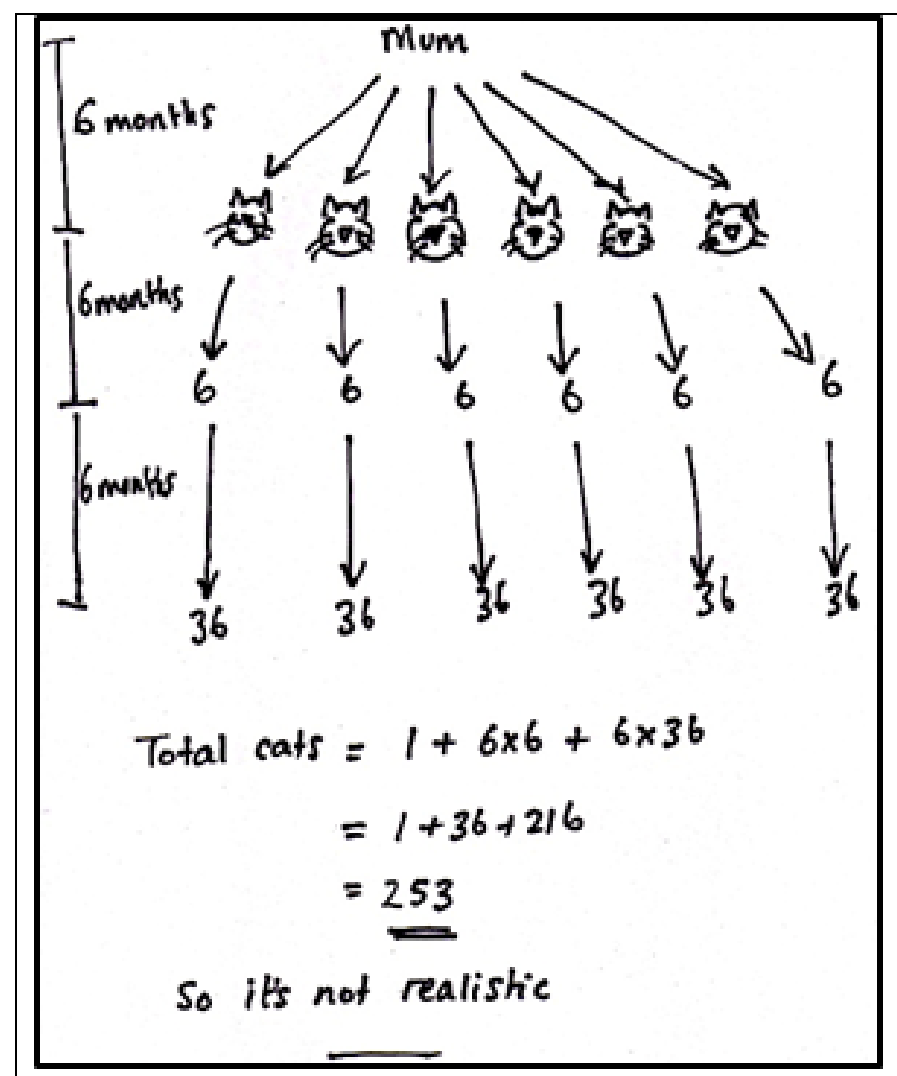

- What has Wayne done correctly?

- What assumptions has he made?

- How can Wayne's work be improved?

\section{Notes from the teacher guide:}

Wayne has assumed that the mother has six kittens after 6 months, and has considered succeeding generations. He has, however, forgotten that each cat may have more than one litter. He has shown the timeline clearly. Wayne doesn't explain where the 6-month gaps have come from.

Figure X.3 Sample work for discussion, with commentary from the teacher guide

\subsection{CONCLUSION}

The two lessons described above contain many features that are not common in mathematics teaching, at least in the US and UK. In both kinds of lessons, there is a strong emphasis on the use of preliminary formative assessment, which enables the teacher to prepare for and adapt interventions to the student reasoning that will be encountered. Students spend much of the 
lesson in dialogic talk, focused on comparing mathematical processes. The successive opportunities for refining the solution enable students to pursue multiple methods and to compare and evaluate them. Finally, pre-designed sample student work is used to foster the development of critical competence.

Early evidence of the impact of these lessons is encouraging. Drawing on a national survey of 1239 mathematics teachers from 21 US states, and interview data from four sites, Research for Action (RFA), ${ }^{6}$ found that a large majority of teachers reported that the use of the Classroom Challenges had helped them to implement the Common Core State Standards, raise their expectations for students, learn new strategies for teaching subject matter, use formative assessment and differentiate instruction.

The National Center for Research on Evaluation, Standards and Student Testing (CRESST) examined the implementation and impact of Classroom Challenges in 9th-Grade Algebra 1 classes (Herman et al. 2015). This study used a quasi-experimental design to compare student performance with Classroom Challenges to a matched sample of students from across Kentucky, comparable in prior achievement and demographic characteristics. On average, study teachers implemented only four to six Classroom Challenges during the study year (or 8-12 days), yet, relative to typical growth in mathematics from eighth to ninth grade, the effect size for the Classroom Challenges represented an additional 4.6 months of schooling. This remarkable gain cannot have come entirely from the particular topics focused on in those few formative assessment lessons, suggesting that there was significant 'seepage' of the pedagogy that these lessons exemplify into the teachers' other teaching - the goal that we set out at the beginning.

\footnotetext{
${ }^{6}$ RFA is a non-profit research organization; see: http://www.researchforaction.org/rfa-study-of-tools-aligned-ccss/
} 
Although teachers felt that that the Challenges benefited students' conceptual understanding and mathematical thinking, they reported that sizeable proportions of their students struggled, and it appeared that lower-achieving students benefited less than higher achievers. This, they suggested, may have been due to the great difference in challenge and learning style required by these lessons, compared with students' previous diet of largely procedural learning.

Finally, in 2014, Inverness Research (IR 2015) surveyed 636 students from 31 trial classes (6th Grade to High School) across five states in the US. They found that the majority of students enjoyed learning mathematics through these lessons and reported that they understood it better, had increased in their participation, and had improved in listening to others and in explaining their mathematical thinking. About 20\%, however, remained unaffected by or disaffected with these lessons. This was because they did not enjoy working in groups, they objected to the investigative approach and/or they felt that these lessons were too long or too difficult. It is our hope, with some evidence in support, that greater exposure to the Classroom Challenges over a longer period will enable lower-attaining students to benefit more, as their teachers learn to broaden their adaptive expertise.

In conclusion, Classroom Challenges appear to provide a model for teachers as they attempt to introduce formative assessment into their everyday classroom practice, but they require a radical shift in the predominant classroom culture. How far teachers transfer this approach into the rest of their teaching is the focus of ongoing research. We are also currently looking at building on this work to design a suite of Classroom Challenges for elementary school ages.

\section{Note}


This paper is based on a plenary given at the 37th Annual Meeting of the North American Chapter of the International Group for the Psychology of Mathematics Education (Swan 2015). ACKNOWLEDGEMENTS

We would like to thank our Shell Centre designer-researcher colleagues at the University of Nottingham, Nichola Clarke, Rita Crust, Clare Dawson, Sheila Evans and Marie Joubert, along with David Martin and Daniel Pead; the observer-researchers around the US, led by David Foster, Mary Bouck and Diane Schaefer; Alan Schoenfeld, Hugh Burkhardt and Phil Daro, who led the project; and the Bill and Melinda Gates Foundation for the funding that made possible this core contribution to their 'College and Career Readiness' strategy for Mathematics.

The 'Having Kittens' task was originally designed by Acumina Ltd. (http://www.acumina.co.uk/) for Bowland Maths (http://www.bowlandmaths.org.uk), and appears courtesy of the Bowland Charitable Trust.

\subsection{REFERENCES}

Barab, S., \& Squire, K. (2004). Design-based research: Putting a stake in the ground. The Journal of the Learning Sciences, 13(1), 1-14.

Bereiter, C. (2002). Design research for sustained innovation. Cognitive studies, Bulletin of the Japanese Cognitive Science Society, 9(3), 321-327.

Black, P., Harrison, C., Lee, C., Marshall, B., \& Wiliam, D. (2003). Assessment for learning: Putting it into practice. Buckingham, England: Open University Press.

Black, P., \& Wiliam, D. (1998). Inside the black box: Raising standards through classroom assessment. London, England: King's College London, School of Education. 
Black, P., \& Wiliam, D. (1999). Assessment for learning: Beyond the black box. Cambridge, England: University of Cambridge, Institute of Education.

Black, P., \& Wiliam, D. (2009). Developing the theory of formative assessment. Educational Assessment, Evaluation and Accountability, 21(1), 5-31.

Burkhardt, H. (2006). From design research to large-scale impact: Engineering research in education. In J. van den Akker, K. Gravemeijer, S. McKenney, \& N. Nieveen (Eds.), Educational design research (pp. 121-150). London, England: Routledge.

Cobb, P., Confrey, J., diSessa, A., Lehrer, R., \& Schauble, L. (2003). Design experiments in educational research. Educational Researcher, 32(1), 9-13.

Cusi, A., Morselli, F., \& Sabena, C. (this volume). The use of digital technologies to enhance formative assessment processes. In D. R. Thompson, M. Burton, A. Cusi, \& D. Wright (Eds.), Classroom assessment in mathematics: Perspectives from across the globe (pp. xxxx). Dordrecht, the Netherlands: Springer.

DBRC [The Design-Based Research Collective]. (2003). Design-based research: An emerging paradigm for educational inquiry. Educational Researcher, 32(1), 5-8.

Evans, S., \& Swan, M. (2014). Developing students' strategies for problem solving in mathematics: The role of pre-designed "Sample Student Work". Educational Designer, 2(7). Retrieved from: http://www.educationaldesigner.org/ed/volume2/issue7/article25/

Hatano, G., \& Inagaki, K. (1986). Two courses of expertise. In H. W. Stevenson, H. Azuma, \& K. Hakuta (Eds.), Child development and education in Japan (pp. 262-272). New York, NY: W. H. Freeman/Times Books/Henry Holt \& Co. 
Herman, J., Epstein, S., Leon, S., La Torre Matrundola, D., Reber, S., \& Choi, K. (2015). Implementation and effects of LDC and MDC in Kentucky districts. CRESST Policy Brief No. 13. Retrieved from http://www.cse.ucla.edu/products/policy/PB 13.pdf

IR [Inverness Research]. (2015). Mathematics Assessment Program (MAP): Project Portfolio. Retrieved from http://inverness-research.org/mars map/xindex.html

Kelly, A. (2003). The role of design in educational research. Educational Researcher, 32(1), 3-4. Kilpatrick, J., Swafford, J., \& Findell, B. (Eds.). (2001). Adding it up: Helping children learn mathematics. Washington, DC: National Academy Press.

Schoenfeld, A. H. (1985). Mathematical problem solving. London, England: Academic Press. Sierpinska, A. (1994). Understanding in mathematics. London, England: Falmer.

Swan, M. (2015). Designing formative assessment lessons for concept development and problem solving. In T. G. Bartell, K. N. Bieda, R. T. Putnam, K. Bradfield, \& H. Dominguez, (Eds.), Proceedings of the 37th Annual Meeting of the North American Chapter of the International Group for the Psychology of Mathematics Education, 5-8 November 2015. East Lansing, Michigan, USA.

Swan, M., \& Burkhardt, H. (2014). Lesson design for formative assessment. Educational Designer, 2(7). Retrieved from: http://www.educationaldesigner.org/ed/volume2/issue7/article24

van den Akker, J., Gravemeijer, K., McKenney, S., \& Nieveen, N. (Eds.) (2006). Educational design research. London, England and New York, NY: Routledge.

Wiliam, D., Lee, C., Harrison, C., \& Black, P. (2004). Teachers developing assessment for learning: Impact on student achievement. Assessment in Education: Principles, Policy \& Practice, 11(1), 49-65. 
Wiliam, D., \& Thompson, M. (2007). Integrating assessment with instruction: What will it take to make it work? In C. A. Dwyer (Ed.), The future of assessment: Shaping teaching and learning (pp. 53-82). Mahwah, NJ: Lawrence Erlbaum Associates.

Wright, D., Clark, J., \& Tiplady, L. (this volume). Designing for formative assessment: A toolkit for teachers. In D. R. Thompson, M. Burton, A. Cusi, \& D. Wright (Eds.), Classroom assessment in mathematics: Perspectives from across the globe (pp. $\mathrm{xx}-\mathrm{xx})$. Dordrecht, the Netherlands: Springer.

\section{AUTHOR BIOGRAPHIES}

Malcolm Swan has, since the 1980s, led the design team in many Shell Centre projects at the University of Nottingham, most recently the Mathematics Assessment Project (MAP). In 2008, he received the first 'Eddie' Prize for Educational Design from the International Society for Design and Development in Education (http://www.isdde.org/isdde/index.htm). In 2016, he became the first recipient, with Hugh Burkhardt, of the Emma Castelnuovo Medal for impact on practice from the International Commission for Mathematical Instruction. He passed away in Spring 2017 after a long illness.

Colin Foster is an Assistant Professor at the Centre for Research in Mathematics Education in the School of Education at the University of Nottingham. He is interested in the design and use of rich mathematics tasks and lessons, and was a designer-researcher on the Mathematics Assessment Project. (colin.foster@nottingham.ac.uk) 